\title{
DWIE STRONY MALARSTWA - ADAM CHMIELOWSKI I JÓZEF CHEtMOŃSKI
}

\author{
THE TWO PATHS OF A PAINTER: \\ ADAM CHMIELOWSKI AND JÓZEF CHEŁMOŃSKI
}

\begin{abstract}
SUMMARY
In metamorphosing himself into Brother Albert, a father to the poor, Adam Chmielowski, a painter had renounced art. For some that painter, Adam Chmielowski, is a lesser man than Albert, the helper of the poor. Yet, these two personas are not mutually exclusive - instead they complement each other, revealing the intimate connection between goodness and beauty. The wonder of Chmielowski's art remains ingrained in Albert's humanitarian work: the sensitivity manifest in Chmielowski's paintings is but another facet of the empathy we detect in Brother Albert's deeds. One persona is no better than the other: Chmielowski is neither inferior nor superior to Albert. If one was to wonder where Adam Chmielowski's path as a painter would have led him, one may examine the path of his friend, Józef Chełmoński. The latter's artistic search for beauty in nature and testimonials of his sensitiveness to goodness are best described by applying to his paintings the following words, a much later saying of Hans Urs von Balthasar: "Beauty (...) dances as an uncontained splendor around the double constellation of the true and the good and their inseparable relation to one another." It was beauty that led Adam Chmielowski to the path of goodness, revealing to him the truth of human nature. Meanwhile, Józef Chełmoński discovered the hidden goodness and glory within the truth and the beauty of nature.
\end{abstract}

KEYWORDS: Adam Chmielowski, Józef Chełmoński, beauty, nature, goodness 
Jerzy Nowosielski twierdził, że malowanie obrazów potrzebne jest tam, gdzie nie można się porozumieć językiem ludzkim, Balthus zaś powiada trafnie, że malarstwo to język nie do zastąpienia żadnym innym. Te słowa malarzy uzupełniają słowa miłośnika i znawcy malarstwa - Paul Valéry uważa, że należy przepraszać za to, że ośmieliło się mówić o malarstwie. Uważam jednak, że o malarstwie mówić i pisać trzeba, pamiętając o tych naukach! Zebrałem tu kilka uwag o dwóch malarzach: Adamie Chmielowskim i przyjacielu jego Józefie Chełmońskim, których prace odsłaniają dwustronność malarstwa.

Chmielowski miał na kolegów wpływ, który umożliwia partycypacja kilku malarzy w zwartości jednej idei kierowniczej, co z kolei umożliwia dialog między nimi. Artyści rozmawiali ze sobą w Monachium¹ ${ }^{1}$, było to w latach ich wspólnego pobytu w stolicy Bawarii. Chełmoński maluje w Monachium w latach 1871-1874, Chmielowski między 1869-1874 - razem studiują tam od roku 1871 do 1874 . Mieli trzy lata na rozmowy. Tematem tych rozmów był zapewne sprzeciw wobec akademii i akademizmu, który to sprzeciw - wówczas wśród młodych powszechny - ujawni się później w tekście Adama Chmielowskiego O istocie sztuki. Radykalną formę przyjmie w odrzuceniu przez ich kolegę Stanisława Witkiewicza wszelkich szkół - jak wiadomo, swego syna Stanisława Ignacego nie posyłał do żadnej szkoły i oburzało go podjęcie przezeń studiów w krakowskiej Akademii. Tematem ich rozmów był też zapewne sprzeciw wobec atmosfery miasta Monachium. Zdaniem polskich malarzy, tworzył ją charakter Bawarczyków, dla których istniały tylko Bier, Würstchen, Brezeln... (piwo, kiełbaski, precle) i upodobanie w miałkim malarstwie... Interesujące, że malarze nasi nie zauważyli upodobania mieszkańców Monachium do muzyki! Bawarzy odwzajemniali się Chełmońskiemu oburzeniem. Na widok jego płócien mówili: „Na, zu viel Leben!“ (no, za dużo życia!).

Chmielowski i Chełmoński - skupieni wokół Brandta i Maksa Gierymskiego w tzw. sztabie - z pewnością omawiali także problemy malarstwa. Problem stwarzał tak zwany sos (monachijski), z którym miał wiązać się Stimmung, czyli nastrój, klimat. Pytali: czy aby obraz miał Stimmung, musi być w sosie zatopiony? Czy musi być ciemny, mroczny? Nazwą „sos” deprecjonowano brązowoszary ton ogólny, ogarniający całość płótna i niwelujący kontrasty barw. Brał się sos bądź ze stosowania asfaltu w podmalówkach, który „wyłaził” po czasie na wierzch, bądź był rezultatem nakładania na warstwę malarską tak zwanego Grundlasur, laserunku pokrywającego cały obraz, w celu

${ }^{1}$ M. Masłowski, Malarski żywot Józefa Chełmońskiego, Warszawa 2014, s. 136. 
narzucenia mu jedności. Laserunek ten dość szybko ciemniał. Branie „sosu” za Stimmung powoduje wieloznaczność terminu Stimmung. W węższym sensie Stimmung jest terminem technicznym języka malarzy w szkole monachijskiej i - wedle Witkiewicza - jest nie tyle projekcją wizji malarza w krajobraz, ile wydobytą i ukazaną malarsko-psychiczną istotą krajobrazu w szczególnym momencie, głównie wieczorem lub nocą. Stimmung otwierałby więc drogę do istoty krajobrazu, którą Witkiewicz psychologizuje. Taki Stimmung nie ma nic wspólnego z sosem. W sensie szerszym Stimmung ma każdy obraz: znaczy tu tyle, co klimat czy atmosfera, która może być jeszcze bardzo różna! Pustka i cisza Nokturnu Adama Chmielowskiego różna jest wszak od ciszy i niemal mistycznej pustki pejzażu Józefa Chełmońskiego Przed wschodem słońca. Jutrzenka. Jest wiele obrazów, które mają Stimmung, nie będąc zalane sosem.

Uwaga na marginesie - pejzaż polski - polnische Landschaft był sprzedażny (verkäuflich)! Ironizowano nawet na jego temat. Jan Świderski, malarz krakowski, recytował mi wierszyk powtarzany pono w Monachium:

Ein bißchen Schnee, ein bißchen Sand, sicher Kowalski oder Brandt, und wenn ein Wolf erscheint dabei, bestimmt polnische Malerei!

Trochę śniegu, trochę piasku; pewnie Kowalski albo Brandt, a gdy przy tym wilk się zjawi, to już na pewno polskie malarstwo.

$\mathrm{Z}$ uwagą na marginesie wiąże się sprawa stosunku do natury: mimesis to naśladowanie czy interpretacja natury, jeżeli zaś mimesis, to jaka? O stosunku do natury z pewnością mówiono, swoiście widział ją „realista” Stanisław Witkiewicz, po swojemu Adam Chmielowski, malując ją z wyczuciem koloru, jej zróżnicowaną wizję miał Chełmoński - dramatyczną, panteistyczną... Po powrocie do Polski Chmielowski z Chełmońskim rozmawiali w warszawskim Hotelu Europejskim ${ }^{2}$. Chełmoński maluje tam w latach 1874-1875; a Chmielowski maluje w Hotelu Europejskim w latach 1875-1877. Razem malują więc i rozmawiają w roku 1875 . O czym? To możemy domniemywać, czytając tekst Adama Chmielowskiego O istocie sztuki ${ }^{3}$. Tekst ukazuje się

2 Tamże, s. 179.

3 „Ateneum”, t. II, z. 4, Warszawa 1876, s. 428-431. Artykuł omówiła obszernie Stefania 
w „Ateneum” w 1876 roku, zatem już po wyjeździe Chełmońskiego do Paryża. Być może jest podsumowaniem rozmów w pracowni z kolegami (głównie Chełmońskim i Witkiewiczem)

Spróbowałem rozczłonkować tekst, wydobywając główne jego myśli.

1. Godność sztuki. Znakomitą większoośc ludzi myślących wszystkich czasów i epok zajmowały pytania odnoszące się do sztuki. Tak się i dziś dzieje; nie tylko estetycy piszą książki w tej materii, ale każdy z ludzi oświeconych ma zwykle na osobisty użytek jakąś teorię, bądź własną, bądź cudzą, i rzecz to jest całkiem naturalna, że przedmiot tak ważny, który tak wiele miejsca w życiu moralnym świata zajmuje, zaciekawia umysły.

2. Teoria sztuki. Zdawało by się pozornie, że po tej tak długiej pracy i tak powszechnej powinnibyśmy już mieć skończoną i sformułowaną teorię sztuki. Tak jednak nie jest; przeciwnie, zawikłanie pojęć na tym polu jest zapewne większe aniżeli na każdym innym.

3. Znaczenie estetyki. Tym bardziej praca na polu estetyki ciekawa i pożyteczna, bo sztuka wiecznie żyje, chyba by duch świata, który życie powoduje, uleciał.

4. Sztuka objawem ducha świata. Sztuka jest tego ducha objawem - za taki uważały i uważają ją wszystkie podnioślejsze umysły.

5. Godność sztuki u różnych narodów. „Zdaje się" mówi p. Karol Blanc', członek Akademii Francuskiej, „że narody przeczuły, że ich sława będzie mierzona dziełami poety i architekta, rzeźbiarza i malarza, bo nie ma narodu, który by nie szanował artystów jako przyszłych świadków swojej wielkości”.

a) $\mathrm{Na}$ pierwotnym Wschodzie i na dolinach Nilu sztuka połączona z najwyższym kapłaństwem była tak czczona, jak wielki kapłan.

Skwarczyńska, Adama Chmielowskiego rozprawa „O istocie sztuki”, w: Studia i szkice literackie, Warszawa 1953 s. 507-525. Autorka charakteryzuje pogląd Chmielowskiego w słowach: „Ujawnione w teoretycznej rozprawie szerokość horyzontów, śmiałość myśli, niezależnej zarówno od wstecznej tradycji, jak i od kosmopolitycznej mody, jest dowodem wysokiego poziomu intelektualnego, surowej rzeczowości, bezkompromisowości i realizmu myślenia jej autora; tym samym rozprawa ta domaga się niejako rozpatrzenia także dzieła miłosierdzia Brata Alberta jako wyniku mądrej, surowej analizy rzeczywistości i analizy obowiązku człowieka w danym układzie sił społecznych oraz obrony jego przed wyjaśnianiem tylko naciskiem czynników irracjonalnych, porywem uczucia lub taką czy inną łatwizną".

${ }^{4}$ Charles Blanc (1813-1882), francuski historyk, krytyk i teoretyk sztuki, autor monumentalnej i po dziś dzień ważnej: Grammaire des arts du dessin: architecture, sculpture, peinture, Paris 1876. 
b) W Grecji bajka o Prometeuszu porywającym ogień niebieski, żeby ożywić glinę, postaciowała wyraźnie podniosłe pochodzenie sztuki. Dlatego nie jest rzeczą dziwną, że najmędrszy z filozofów, mistrz Platona, był rzeźbiarzem i że wymodelował trzy Gracje. U Hellenów poczucie religijnego szacunku było przywiązane do wspomnienia Fidiasza, i potomkowie tego wielkiego człowieka mieli obowiązek z ojca na syna pokazywać jako miejsce godne czci pracownię, gdzie wyrzeźbił Jowisza Olimpijskiego. Płaskorzeźba rzeźbiarza Alkamena była umieszczona w szczycie świątyni Eleusis. Miasto Pergam w Mizji kupiło z funduszów publicznych pałac zrujnowany, żeby ocalić kilka murów, na których były jeszcze malowidła Apellesa, i mieszkańcy zawiesili zwłoki tego malarza sławnego w sieci ze złotych nitek.

c) Surowsi od Greków Rzymianie odziedziczyli jednak od nich w części szacunek dla artystów. Cycero opowiada, że Leliusz Fabiusz, który liczył pomiędzy swoimi tylu konsulów i którego rodzina tyle razy tryumfowała, chciał podpisać swoje imię na malowidłach wykonanych jego ręką w świątyni Zbawienia i dodał sobie przydomek „Fabiusz Pictor".

d) Na koniec, w czasach nas bliższych, najwspanialszy z niemieckich cesarzy, ten, który łączył w sobie dumę germańską i wyniosłość kastylijską, Karol V wymówił to głośne słowo: „Tycjan na to zasługuje, żeby mu służył Cezar".

6. Teoria pierwsza i jej krytyka.

a) Jest wprawdzie w pewnej sferze moralnej teoria, która chce widzieć w sztuce rozrywkę umysłu, albo pożyteczną sługę nauki moralności, polityki, nareszcie religii.

b) Nie sądzę jednak, aby było właściwie rachować się z takimi teoriami - albo dyskutując je, wkraczać w dziedzinę pojęć, z których te teorie wypływają - za ciasny to świat.

7. Teoria druga i jej krytyka.

a) Teoria. Inaczej jest, jeżeli weźmiemy pod uwagę autora, którego przytaczałem. Uważa on takie pojęcia, jak ideał, piękno, wzniosłość za elementy do budowy swojej teorii i wielu ludzi buduje ją nie tak dobrze, ale $\mathrm{z}$ tego samego materiału.

b) Krytyka. Pojęcia jednak te są względne, każdy chętnie to przyzna. Niepodobna dowieść, dlaczego łańcuch gór daje widok wzniosły, ryk 
burzy na oceanie wzniosłą harmonię - dlaczego drzewo jest piękne, a inne brzydkie, bo piękna w naturze we właściwym znaczeniu nie ma, ono tylko w nas samych - my je odnajdujemy i nie tylko artyści z fachu.

8. Definicje Charles'a Blanca 5 .

a) Ideał w nas jest to wspomnienie poprzednio widzianej doskonałości i nadzieja zobaczenia jej jeszcze.

b) Sztuka nie jest naśladownictwem, ale tłumaczeniem natury, jej najwyższą misją jest objawiać piękno, którego natura posiada zarodki, rozjaśniać pomieszane, upraszczając to, co zawiłe w niej.

c) Styl w znaczeniu ogólnym jest to prawda typowa.

d) Piękno nie ma określenia jednego dla wszystkich sztuk.

9. Krytyka. Oto są niektóre definicje pana Blanc. W nich się zawiera sens teorii, o których mowa:

a) choć ciekawe same w sobie,

b) nie są jednak wolne od pewnej zawiłości filozoficznej i

c) nie każdemu dostępne,

10. Uzasadnienie krytyki. Właśnie z powodu, że

a) pojęcia użyte w tej teorii za kamień węgielny są względne i

b) jako takie nie dosyć silną podstawę stanowią,

c) a stosowane w praktyce nie przystają do wielu utworów sztuki pełnych zalet.

11. Propozycja Chmielowskiego.

a) Dzieło sztuki. Znacznie prostszą wydaje się być rzeczą przyjąć i uważać za dzieło sztuki każdy szczery i bezpośredni objaw duszy człowieka w jego dziele czy dzieło, w którym dusza zaklęta, uważane materialnie, będzie trwałe na tysiące lat, czy razem $\mathrm{z}$ chwilą ulotne. Istota rzeczy zawsze jest jedna.

b) Logos sztuki. Wszakże Bóg objawia się jednakowo w drobnej trawie i w wielości światów, tak i dusza człowieka, istota sztuki, objawia się

i) zarówno w poemacie, jak i

ii) $\quad \mathrm{w}$ dobrze przedstawionej przez aktora roli na scenie $\mathrm{e}^{6}$.

${ }^{5}$ Grammaire des Arts du Dessein..., Paris 1876.

${ }^{6}$ M. Morstin-Górska przypuszcza, że Chmielowski, pisząc te słowa, miał na myśli znakomitą aktorkę Helenę Modrzejewską. Por. Adam Chmielowski - Brat Albert (Szkic życiorysu), „Verbum” 1936, s. 76. Analogiczną intuicję rozwija Marcel Proust, La prisonnière, Paris 1954, s. 253. 
c) Hierarchizacja:

i) piękna róża kwieciarki,

ii) dobrze noszona suknia,

iii) gustowny klomb w ogrodzie

- mogą mieć większe w sztuce znaczenie aniżeli niejeden obraz i rzeźba,

- są często więcej warte niż duże gmachy z kamienia.

d) Nieokreślony zakres sztuki. Ani podobna zliczyć form, w których sztuka się objawia; tak ich wiele i tak rozmaite.

e) Każdy jest artysta: że każdy, kto człowiek, jest w pewnym sposobie artystą.

f Trudno przypuszczać, żeby sztuka ze swej istoty była jakimś osobnym światem, udziałem niektórych. Gdzież miejsce dla takiego świata? Ani na ziemi, ani na niebie, najprędzej w mózgu niektórych ludzi.

g) Jeżeli więc sztuka wydaje się czymś oderwanym od życia, wina to barbarzyństwa ludzi, fałszywych teorii, nie zaś samej sztuki.

12. Anty-akademia (akademizm). Tej nie trzeba się uczyć.

13. Paideia artysty. Trzeba tylko duszę swoją kształcić i podnosić.

a) Wielki człowiek robi wielkie dzieło, mały człowiek i jego dzieła są drobne, bo

14. Twórczość

a) nie jest udziałem człowieka, chyba tylko w przenośni tak by wyrazić się można.

b) Udziałem człowieka jest siebie samego zakląć w słowo, kamień, tony

15. Cel sztuki: przez to jest nieśmiertelny nawet na ziemi, nie umiera, zostaje jako przyjaciel albo mistrz dla tych, co przychodzą po nim. Szereg tych przodków moralnych to bogactwo i szlachectwo ludzkości, nitka, co ją łączy z Bogiem, droga do prawdy, to jedyny bezpośredni cel sztuki.

16. Sztuka fałszywa. Jako antytezę sztuki prawdziwej, wyrażającej się przez styl - czyli indywidualność duszy, można postawić sztukę fałszywą, udaną, wyrażoną przez manierę, sposób, sztukę nauczoną. Bywało tak i bywa, że sztuka epok całych lub indywiduów schodzi z tronu, żeby służyć nie tylko myślom i rzeczom światowym, ale namiętnościom. Poniżająca to służba i złe usługi; upadły anioł ciągnie społeczeństwa do upadku - dosyć na dowód porównać historię ogólną z historią sztuki. 
a) Styl właśnie jest to szczerość, przyrodzony głos duszy, jej kształt, jej język.

b) Maniera to przedrzeźnianie stylu, to głos i język papugi, kalectwo kształtu.

c) Przedmiot dzieła sztuki nie ma z jej istotą wspólności, wyjąwszy to jedynie, że zawsze od niej zależy. Z wyboru przedmiotu można sądzić o umyśle artysty, ale nie o tym, co artystę stanowi - w dziele sztuki obchodzi to, co artysta czuł, nie to, co myślał: czyż znawcę obchodzi tytuł symfonii, przedmiot architektury albo obrazu? Zapewne obchodzi, ale z innych względów; dzieła sztuki są duchem i do ducha naszego mówią. Religia, moralność, ciążenia naukowe, polityka epok i czasów wpływają na przedmioty, które sztuka traktuje, ale przedmiot dzieła sztuki to tylko jej zewnętrzna strona, to tylko jej suknia.

d) Sztuka w znaczeniu ścistym - martwa. Po tym, co napisane, zaledwie potrzebuję dodawać, że sztuki pojedyncze uważane w znaczeniu ich ścisłym, zatem kiedy usuniemy pierwiastek ich mistyczny, są zdolnościami, które człowiek zdobywa za pomocą rozumu, woli, zalet organizacji fizycznej. Mają one niektóre prawa niezbite, są oparte na obserwacji natury, posługują się nauką, są prawie naukami. Na zasadach tych nauk można pisać dobrze wiersze albo muzykę, malować i rzeźbić; produkcje te jednak nie są nikomu potrzebne ani pożyteczne i nie mają żadnego miejsca w sztuce prawdziwej.

e) Sztuka żywa, ekspresja („Istotą sztuki jest dusza wyrażająca się w stylu”). Uważając rzecz odwrotnie, weźmy za przykład niektóre dzieła wieków średnich. Są pełne uroku przez prostotę, naiwność i ekspresję posuniętą do najdalszych granic, to ich styl, a jakże mało sztuki w znaczeniu ścisłym! Wielki Rafael, o którym mówią, że w niektórych obrazach zobaczył niebo, nie zdołał dorównać ekspresją naiwnemu Fra Angelico. Streszczam więc myśl moją: „Istotą sztuki jest dusza wyrażająca się w stylu”.

Chmielowski wykłada swoisty ekspresjonizm i antyestetyzm, jeżeli z estetyzmem mamy do czynienia wówczas "gdy piękno staje się formą, która nie jest pojmowana w sposób tożsamy z bytem, duchem i wolnością, wówczas oznacza to, że powrócił wiek estetyzmu, (...) (brak mu) siły bytu, która tkwi 
w ustanowieniu formy"”. Dla Chmielowskiego sztuka jest ważna, ponieważ zajmuje wiele miejsca w życiu moralnym świata. Jednak teorii, która ze sztuki czyni sługę nauki moralności, polityki, nareszcie religii, Chmielowski nie uznaje. Nie znajduje jego akceptacji teoria Charles’a Blanc, dla którego kluczowe są pojęcia, takie jak: ideał, piękno, wzniosłość, w których to wartościach uczestnicząc, sztuka tłumaczy (nie naśladuje!) naturę. Sensem metafizycznym sztuki jest „objawiać piękno, którego natura posiada zarodki”.

Mimo że teoria Blanca wygląda zachęcająco, Chmielowski ją odrzuca ze względu na relatywność użytych pojęć $\mathrm{i}$ - według niego - ich zbyt wąski zakres. Takie jak u Blanca rozumienie sztuki prowadzi do uprawiania „sztuki w znaczeniu ścisłym", polegającej tylko na wiedzy i płynącej z niej umiejętności wytwarzania wierszy, kompozycji muzycznych, obrazów, rzeźb... sztuki pozbawionej pierwiastka mistycznego - dzieła, wytwory takiej sztuki w konsekwencji nie są potrzebne ani pożyteczne. Owej sztuce w znaczeniu ścisłym przeciwstawia Chmielowski „sztukę prawdziwą, która jest ekspresją tworzącą styl. Jest też sztuka (...) objawem ducha świata”. Prawdziwe dzieło sztuki to „każdy szczery i bezpośredni objaw duszy człowieka w jego dziele” (dodałbym - i ducha świata). Dlatego „każdy, kto człowiek, jest w pewnym sposobie artystą" (napisał to dziesiątki lat przed Josephem Beuysem!). Prawdziwa sztuka nie może być oderwana od życia, zaś jej „istotą (...) jest dusza wyrażająca się w stylu".

Myśli Chmielowskiego nie są spójne, bowiem czyż styl musi być pozbawiony piękna bądź wzniosłości, pozbawiony innych wartości artystycznych krążących wokół piękna...? Niespójności te pozostawię tutaj na boku, istotne jest dla mnie, że Adam Chmielowski odchodzi od sztuki nawet pojętej jako „dusza wyrażająca się w stylu". Przeważy dlań jej strona moralna. W konsekwencji podejmie próbę wstąpienia do jezuitów, w nowicjacie jezuickim w Starejwsi jest od września 1880 do kwietnia 1881 . W tym to roku następuje zmiana stanowiska w sprawie sztuki - o czym świadczą listy do Chełmońskiego i do Modrzejewskiej (wysłany na ręce Chełmońskiego), oba z października 1880:

Do Józefa Chełmońskiego - październik 1880

[Starawieś], październik $1880^{8}$

${ }^{7}$ H. Urs von Balthasar, Chwała, tłum. E. Marszał, J. Zakrzewski, Kraków 2008, s. 19.

8 „Przegląd Powszechny” t. 204 (1934), s. 3-6; przedruk „Nasza Myśl” r. 3 (1934), s. 1-4; ks. K. Michalski, Brat Albert, w setna rocznicę urodzin (1846-1946), Kraków 1946, s. 187-190; J. Wegner, Józef Chełmoński wśsietle korespondencji, Wrocław 1953. 
Kochany Józefie.

Posyłam Ci obraz Matki Boskiej, który mam po matce. Powieś go nad łóżkiem, żeby ta dobra Pani, którą przedstawia, strzegła Ciebie i twojego domu. Posyłam Ci książeczkę, z której się dowiesz wielu powodów, dla jakich ludzie do zakonów wstępują. Przeczytaj ją uważnie dla mojej miłości. Posyłam Ci także niedokończony list, który do Pani Heleny pisałem, bo wiele rzeczy, które do niej napisałem, Tobie bym także był napisał. Zanadto dobry jesteś artysta, żebyś miał nie wiedzieć, co jest ze sztuką, i jak jest i brać na serio estetyczne błazeństwa; zanadto też znowu rozumny jesteś człowiek, żebyś miał sądzić, że Pana Boga nie ma, a światy i ludzie z jakiegoś przypadku powstały. Dlatego Ci piszę i radzę jak twój szczery brat i kolega, żebyś się ratował i po prostu, po chłopsku do spowiedzi poszedł, jak możesz najprędzej: żebyś miał grzechy czerwone jak krew, wybieleją Ci jak śnieg, bo za nie Chrystus Pan odcierpiał na krzyżu. Nie ma tu co wiele myśleć i rozumować, bo to są Boskie i straszne tajemnice, ani nie ma $\mathrm{z}$ tymi rzeczami żartu i zwłoki, bo taka zabawa może kosztować miliardy lat męki. Jako ludzie cieleśni jesteśmy synami naszych rodziców, bo z ciała rodzi się ciało, ale przez chrzest rodzimy się po raz drugi nie $\mathrm{z}$ ciała, ale $\mathrm{z}$ ducha Panu Bogu za synów. Za takich nas Pan Bóg przyjmuje i jako tacy jesteśmy zapisani w niebie: „Bogowieście i synami Najwyższego wy wszyscy jesteście”, a tego charakteru nic nigdy zmazać $z$ nas nie może. Kto to wie, ten widzi jasno, co jest piekło, i rozumie doskonale, jak straszną rzeczą jest grzech, przez który Bóg nas, choć synów, odrzuca - a jeślibyśmy w grzechu pomarli, to na tamtym świecie jest ta męka bez końca i rozpacz, żeśmy dobrowolnie najwyższą naszą godność i szczęście utracili. Nie chcieliśmy Bogu służyć, pełniąc, co kazał, więc zamiast kochać, musimy przeklinać wiecznie. Mój drogi Józefie, jeżeli z Panem Bogiem związek zerwałeś, zawiąż go na nowo, i żyj jak prawy syn Boski, bo wielka jest godność twoja jako chrześcijanina na niebie i na ziemi. Kto z Bogiem zerwał, zawiązał z kimś drugim i tamtemu dał nad sobą prawo. Nie ma nic trzeciego, ani tu, ani tam - jest tylko Bóg albo diabeł. Nicości nie ma po śmierci, bo dusza nieśmiertelna jest. My mamy wolę robić, jak chcemy, $i$ iść na prawo albo na lewo, a czy tak trudna ta droga na prawo? Nie powiem Ci: idź do zakonu, masz żonę i dziecko. Małżeństwo to też zakon bardzo święty i ma cały szereg świętych obowiązków, wystarcza, żeby człowieka dobrej woli do nieba zaprowadzić, ale Ci radzę, żebyś przykazań pilnował, a do spowiedzi szedł, jak możesz często i ile razy Ci się zdaje, żeś się zawalał i na swoich nogach nie stoisz. Pan Bóg wie dobrze, w jakim nikczemnym garnku duszę nosimy, dlatego dał spowiedź jak krynicę, żebyśmy się w niej myli, bo życie 
brudzi każdego jak błoto. Dał też Ciało i Krew Syna, żebyśmy tę biedną duszę karmili; nie może dusza bez tej tajemniczej strawy żyć. Taka sama to karma dla niej, jak chleb i mleko dla ciała. Prawda jest, że to tajemnica niepojęta, ale też Pan Bóg dał coś nieznanego do serca. które poświadcza w głębi człowieka, że tak jest, nie inaczej. Komuż wreszcie wierzyć w tych tajemnicach, jeżeli nie Chrystusowi Panu nie wierzyć? Powiedział o tych rzeczach, napisane zostawił, cudami poświadczył, a wszystką krwią ich prawdę przypieczętował. Jeżeli tym nie zasługuje na wiarę i jeżeli nie jest to istotnie Bóg, Syn Boga żywego, to chyba jest jakiś potworny szalbierz, który fałsze i błędy śmiercią potwierdza. Czy można to przypuścić? Czy można przypuścić, że te tysiące męczenników, ćwiartowanych i palonych - to tylko maniaki szalone, a te znowu tysiące innych ludzi, co w Kościele i wierze żyli i umierali, to półgłówki? Zatem ostatnia racja i prawie i prawda zostanie przy tych, co zabijają, kradną i gwałcą, przy tych, co mówią zawsze „może”, nigdy „tak”. Juźci mają rację, jeżeli Boga nie ma ani przyszłego życia. Ale przypuściwszy nawet, że tylko ci ostatni mają rację, przypuść też jeden raz na tysiąc, że prawda jest po stronie Chrystusa i Jego wyznawców. Nuż więc po śmierci okaże się, że tak jest, nie inaczej, cóż wtedy? Straszna to gra i straszne ryzyko, nawet przeciwko tej jednej szansie. Na ostatku Ci piszę, żebyś sobie tego listu lekce nie ważył, ale raczej uważał dobrze, czyj to jest głos, co do Ciebie mówi. Jać piszę ten list, bom Twój kolega, ale więcej daleko pisze do Ciebie moja miłość chrześcijańska - a czy wiesz, co to jest miłość? - Miłość jest Bóg, Duch Święty jest miłość. Dlatego Ci radzę, żebyś dobrze pomyślał, zanim ten list do kąta rzucisz, patrz, co robisz. To ostatnie Ci radzę, jako Twój wierny kolega, który szczerze pragnie, żebyśmy przyjaciółmi byli nie tylko przez życie, ale na wieki mieli złączone dusze i byli razem przez przyjaźń taką, dla której nie ma odległości ani czasu. Pragnąłbym jesienne włókna „babiego lata”, które nas wiążą, zamienić na łańcuch nie do rozerwania przyjaźni duchowej. Całuję Cię serdecznie, Twojej żonie rączki całuję, choć nieznajomy. Do widzenia mój drogi, proszę Cię, żebyś paroma słowy odpisał. Starawieś, poczta Brzozów - Galicja - Adam Chmielowski. Zacząłem nowicjat, czuję się bardzo szczęśliwy. Maluję i zapewne będę malował dużo i lepiej aniżeli dotąd. Zdrowszy jestem. Sygieta pozdrawiam serdecznie, posyłam mu też książeczkę. Mógłbyś mu rozumu do głowy napędzić, dobry jest chłopiec, ale ma w głowie jak w kotle. Katechizmu nie umie, jak my wszyscy artyści; miesza wszystko do kupy, nie wiedząc, że człowiek to nie zwierzę, wbrew wszystkim naukowym badaniom, razem z Darwinem i doktorami. Miesza ludzi i zwierzęta, nie wie, że Bóg i duch ludzki są to rzeczy i pojęcia zupełnie różne, bo jedno jest stworzone i marne, a to drugie jest niestworzone i wieczne. Religia znowu nie wiąże ciała i materii z jej Stworzycielem, bo to nie jest podobną rzeczą, ale wiąże religia 
duszę z Panem Bogiem wiecznym węzłem. A Kościół znowu katolicki to nie budynek z lichymi najczęściej obrazami, w którym się często modlą dewotki i wielu do niego zapisanych katolików fałszywych, gdzie znaleźć też można złych i głupich księży, ale Kościół to jest sukcesja nieprzerwana świętych: ludzi, czynów i zasad, która łączy w jedną całość mnóstwo ludzi, którzy żyli na świecie od dawna i żyją, niektórzy są w niebie i w czyśćcu, inni na ziemi, a wszyscy są złączeni w jednym duchu, wspomagają się wzajemnie i ze sobą komunikują. To jest Kościół katolicki, święte ciało, choć w nim dużo członków chorych albo umarłych. Ściskam Sygieta i jego łasce i przyjaźni się polecam.

Wprawdzie Adam Chmielowski maluje, ale nie jest to już naczelny nurt jego powołania. Nastąpiło przesunięcie akcentu. Bardziej radykalny jest list do Heleny Modrzejewskiej (list załączony do listu do Chełmońskiego) - z października $1880^{9}$ :

\section{Droga Pani Heleno. ${ }^{10}$}

Posyłam Pani tę mądrą książeczkę na pamiątkę. Wesołą nowinę też posyłam, wesoła dla mnie i szczęśliwa nad wszelki wyraz; wstąpiłem do zakonu, za kilka dni dostanę suknię jezuicką, tę sławną czarną sukienkę, pod którą tylu Świętych zwyciężało świat i siebie, a tylu bohaterów krwią się oblało za Boga i wiarę. Znam dużo myśli Pani, znam Jej dobre serce dla mnie i szczerą przyjaźń, wiem także, że dusza Pani jest jak harfa o złotych strunach, której żadna wzniosła melodia nie jest obca - wiem dobrze to wszystko i dlatego sądzę, że Pani ucieszy się moją teraźniejszą radością. Już nie mogłem dłużej znosić tego złego życia, którym nas świat karmi, nie chciałem już dłużej tego ciężkiego łańcucha nosić. Świat, jak złodziej, wydziera co dzień i w każdej godzinie wszystko dobre z serca, wykrada miłość dla ludzi, wykrada spokój i szczęście, kradnie nam Boga i niebo. Dla tego wszystkiego wstępuję do zakonu; jeżeli duszę bym stracił, cóżby mi zostało? Słowacki, którego Pani tak bardzo lubi, mówi, że „talenta”, są to w ręku szalonych latarnie, ze światłem idą topić się do

9 „Przegląd Powszechny” t. 204 (1934), s. 6-8; przedruk. „Nasza Myśl” [Starawieś, październik 1880].

${ }^{10}$ Modrzejewska wspomina wszystkich w swych pamiętnikach. Oto co pisze o Adamie Chmielowskim: „Drugi z trójcy to Adam Chmielowski. Był on i jest jeszcze, kiedy te słowa piszę, chodzącym wzorem wszystkich cnót chrześcijańskich igłębokiego patriotyzmu prawie bezcielesny, oddychający poezją, sztuką i miłością bliźniego, natura czysta i nieznająca egoizmu, której dewizą powinno być: Szczęście dla wszystkich, Bogu chwała i sztuce! Brał udział w powstaniu i w potyczce stracił nogę. W sztuce malarskiej był bardzo subtelnym kolorystą", Wspomnienia i wrażenia, tłum. M. Promiński, Kraków [1957], s. 241. 
rzeki"11. Jakież to okropne, a jakże często prawdziwe. Choć nie wiem, czy talent mam, czy tylko talencik, to wiem jednak z pewnością, że jestem w drodze do powrotu znad samego brzegu tej smutnej rzeki, a wieluż ich pochłonęła, tych nieszczęśliwych topielców i wielu Wciąż pochłania! Sztuka i tylko sztuka, byle jej uśmiech albo cień uśmiechu, byle jedna róża $\mathrm{z}$ wianka bogini, bo z nią sława i dostatek i osobiste zadowolenie - mniejsza o resztę; gubi się w szalonej gonitwie rodzinę, moralność, ojczyznę, związek z Bogiem, gubi wszystko, co dodatnie i święte - lata uciekają, organizacja fizyczna niszczeje, a z nią i talent tak zwany - poza tym śmierć - ale żebyż tylko śmierć i nicość, ale i to nie, bo dusza nie umiera nigdy. Śmierć to tylko początek nowego życia, które trwa tysiące lat w nieskończoność - życie rozpaczy i nieszczęścia. I czy ten miałby być los człowieka, co przez chrzest Synem Boga został? Boć sam Pan Bóg kupił nas za synów i wszystką krwią swoją zapłacił, że już tylko woda pociekła; nie mógł ich taniej dostać, żeby przedział między człowiekiem stworzonym i Stworzycielem zapełnić. Wiele myślałem w życiu, kto jest ta królowa sztuka - i przyszedłem do przekonania, że jest to tylko wymysł ludzkiej wyobraźni, a raczej straszne widmo, które nam rzeczywistego Boga zasłania. Sztuka to tylko wyraz i nic innego, dzieła tej tak zwanej sztuki, są to zupełnie przyrodzone objawy naszej duszy, są to nasze własne dzieła i mówiąc po prostu, dobra jest rzecz, że je robimy, bo to naturalny sposób komunikacji i porozumienia się między nami. Ale jeżeli w tych dziełach kłaniamy się sobie - a oddajemy wszystko na ofiarę, to, choć to się nazywa zwykle kultem dla sztuki, w istocie rzeczy jest tylko egoizmem zamaskowanym; ubóstwiać siebie samego - to przecież najgłupszy i najpodlejszy gatunek bałwochwalstwa...

Sztuka to nadal „objawy naszej duszy, jej wyraz, które są o tyle usprawiedliwione, o ile służą komunikacji i porozumieniu się między nami”. Natomiast kult sztuki jest w istocie kłanianiem się sobie samemu, zamaskowanym egoizmem, wręcz bałwochwalstwem.

${ }^{11}$ J. Słowacki, Kordian. Oto słowa w kontekście wypowiedziane przez Kordiana, a skierowane do Laury:

Tak, gdy mię spalą męczarnie,

To będę świecił ludziom próchnem moich kości.

Talenta sa to $w$ ręku szalonych latarnie,

Ze świattem idą prosto topić się do rzeki.

Lepiej światło zagasić i zamknąć powieki.

Albo kupić rozsądku, zimnych wyobrażeń,

Zapłacić za ten towar całym skarbem marzeń...

Por. Dzieła, t. VI. Dramaty, oprac. E. Sawrymowicz, Wrocław 1952, s. 195. 
Listy te wywarły wpływ na Chełmońskiego, choć nie od razu. Jaki? Szeroko mówi o nim naoczny świadek, Pia Górska w rozdziale książki Paleta i pióro, zatytułowanym Jak Chełmoński patrzył na świat $i$ ludzi ${ }^{12}$. Chełmoński odrzuca religię sztuki, jednak nie rezygnuje z malarstwa. Tyle że w malarstwie szuka prawdy i dobra natury. Być może ducha świata, o którym mówił Chmielowski. W każdym razie kładzie nacisk na piękno. Adam Chmielowski położył nacisk na dobro. W konsekwencji palące staje się dlań pytanie o relacje sztuki i religii.

Czy Brat Albert potępiał sztukę, czy przeciwstawiał ją religii? Czy życie sztuką przeciwstawiał życiu świętemu? Droga jego była przeciwna do drogi Van Gogha, o czym pisał ks. Konstanty Michalski ${ }^{13}$ w opublikowanej w 1946 książce o Bracie Albercie. Praktyka jest znana. Chmielowski został bratem Albertem. A w teorii? Młodopolską religię sztuki (o ile to coś znaczy) z pewnością przeciwstawiał chrześcijaństwu; czy jednak sztukę istotną przeciwstawiał chrześcijaństwu? Odpowiedzi wprost nie znamy, wskazówka nie wprost pozwala się domyślać, że odsłoniła się przed nim ta strona sztuki, która wiąże się z dobrem - mówi się, że w obrazie Ecce Homo. Później Jacka Malczewskiego, który chciał doń dołączyć, do albertynów nie przyjął, lecz jego malarstwa nie potępił, kazał Jackowi wracać do sztalug. Poza tym sam - już zakonnik - malował, by zdobyć trochę grosza dla ubogich.

W sposobie bycia, stroju, dezynwolturze Brata Alberta widać wpływ sposobu życia cyganerii monachijskiej i warszawskiej. Nie było w nim nic z dostojnego „zakonodawcy”, było w nim dużo artysty malarza. Rękę artysty widać w kroju habitów albertynów i albertynek, które są po prostu eleganckie, widać na Kalatówkach w architekturze kaplicy i w urządzeniu jej wnętrza, a także w duchu skrajnego minimalizmu wnętrza jego celi tamże, który językiem pobożnym nazywa się ubóstwem.

Myślę, że Józef Chełmoński to ktoś, kim byłby Adam Chmielowski, gdyby nadal malował. Jego skrajna prostota, ubóstwo lat ostatnich, stosunek do natury, rodzaj ludzi, którzy mu byli bliscy: o. Benvenuty - kapucyn, prosty proboszcz wiejski ks. Franciszek Pełka i Brat Albert! Zaryzykuję tezę: Chełmoński był bratem Albertem malarstwa.

Jeżeli Chmielowski w Ecce Homo powiedział: homo sive Deus, Deus sive Homo, to Chełmoński w niektórych pejzażach mówi, Deus sive Natura, natura sive Deus. Panteizm Chełmońskiego w płótnach Przed świtem (zachwyt

\footnotetext{
${ }^{12}$ P. Górska, Paleta i pióro, Kraków 1960, s. 111.

${ }^{13}$ Ks. K. Michalski, Brat Albert, w setna rocznice urodzin (1846-1946), dz. cyt.
} 
nad kroplą rosy na źdźble trawy, kosmos w kropli, mikrokosmos i makrokosmos) i Chmielowskiego w Zawalu. Adam Chmielowski namalował Zawale, Czarnokozińce. Te obrazy Chmielowskiego porównywałbym z pejzażami Józefa Chełmońskiego: Przed świtem, Wschód księżyca, Droga w polu, Koncert $\dot{z} a b$, Czajki, zalana łąka... Z obrazami Chmielowskiego nie porównywałbym jednak tych obrazów Chełmońskiego, których wiele i w których coś się dzieje: scen rodzajowych, jak Babie lato, Burza, Na folwarku, Jesień czy Owczarek..., koni, zaprzęgów.... Analizy formalne niewiele tu wniosą. Wskazane są one w przypadku Zawala, nie dadzą wiele w przypadku pejzaży Chełmońskiego. Jego Przed świtem to płótno podzielone horyzontem na pół, kolorystycznie działa zestawienie nieba z ziemią. Kompozycja jest zrównoważona, ale to w tym przypadku mówi niewiele, istota obrazu tkwi gdzie indziej. Gdzie? W nieskończoności? Obraz można ciągnąć w obie strony w nieskończoność? Także otwiera się na nieskończoność niejako widoczną poprzez obraz, na „ducha świata".

Czy jest to sztuka narodowa? Terminem tym określano malarstwo podejmujące polski temat, choć malarstwo samo mogło być z ducha niemieckie. O takim malarstwie pisał Józef Czapski krytycznie przed wojną, atakował malarstwo skupione tylko na temacie narodowym, którego nie zajmowała forma malarska obrazu. Atakował Matejkę, co do którego zmienił zdanie pod koniec życia, dostrzegłszy w jego płótnach ekspresję wartości moralnych.

Chełmoński malował świat, którego już nie ma, który umarł na moich oczach; pamiętam orkę krowami, żniwa kosą, a nawet sierpem, stawianie snopków...

10 sierpnia 1909 JózefChełmoński napisał list do Stanisława Witkiewicza ${ }^{14}$, w którym ujawnia swą postawę artystyczną. Tę stronę malarstwa, której poniechał Chmielowski:

Kochany i Najukochańszy Stasiu!

$Z$ radością wielką odebrałem Twoje kochane pismo. (...) znowu te same dźwięki spod serca - ileż im od tak dawna dłużnym jestem? Zawsześ ten sam. Przychodzą mi na pamięć te rozpromienione miłością Twoją godziny walk i cierpień w Monachium, potem w Warszawie! Wszystko przeszło, a życie jest za krótkie, można by jeszcze co zrobić. Dziś, kiedy do Warszawy pojadę, to prócz Adama czuje się bardzo samotnym nie dla jakichś powodów starości, ale że nie ma młodzieży, która by chciała podjąć ten sam trud uczenia się z miło-

${ }^{14}$ M. Masłowski, Malarski żywot Józefa Chełmońskiego, dz. cyt., s. 363. 
ścią dla prawdy, tej samej w naturze Bożej - że jakby urągała świętości natury i jej nieskazitelnej piękności. Pewny jestem, że minie to prędko, jak zastępowanie ubóstwa fantazji europejskich artystów okradaniem bogactw artystów japońskich (secesja). Ale milczę i okładam się dla ciepła i grzeję sercem takiego Wojtka Piech.[owskiego], który teraz jest u mnie, choć trochę zniedołężniały, i który tu jest jeden, bo nie mogę drugich już odnaleźć, tak ich życie przemłóciło. Wczoraj wróciłem z Ukrainy, w tych przestworzach bezmiernych pól szukałem dawnych uczuć, to już wszystko się przemieniło, tylko nie przemieniły się te pragnienia widzenia ich i cieszenia się nimi. W niektórych studiach (chciałbym Ci je pokazać) szukałem słońca tego mocnego na Podolu i Ukrainie; pragnąłbym wynaleźć jaki sposób wyrażenia tych zamiarów, alem go jeszcze nie znalazł.

Mowa w tym liście o miłości i relacjach piękna i prawdy, a także świętości natury, czyli o tej stronie malarstwa, która zmieniła Adama Chmielowskiego w Brata Alberta, a która dla Józefa Chełmońskiego dana jest poprzez malarstwo. Chodzi więc o „trud uczenia się z miłością dla prawdy, tej samej w naturze Bożej - o świętość natury i jej nieskazitelnej piękności. O poszukiwaniu w tych przestworzach bezmiernych pól (...) dawnych uczuć, które się nie zmieniły, pragnienia widzenia ich i cieszenia się nimi”. Chce wynaleźć sposób wyrażenia, ekspresji tych zamiarów, ale go nie znajduje.

Życie i dzieło Adama Chmielowskiego i Józefa Chełmońskiego odsłaniają dwustronność sztuki, w tym przypadku malarstwa. Prace obu malarzy uczestniczą w pięknie, które można by dookreślić jako romantyczne, gdyby nie obraz Ecce Homo, który nie jest romantyczną wizją Jezusa. Natomiast pejzaże jednego i drugiego określiłbym jako romantyczne. Jednak nie jest to teraz aż tak ważne. Piękno jako wartość estetyczna jest ich ostatecznym usprawiedliwieniem. Jest jednak w obrazach tych obecne coś jeszcze. Hans Urs von Balthasar napisał te słowa: „piękno (...) jako niepojęty blask otacza podwójną gwiazdę prawdy i dobra oraz ich nierozerwalne odniesienie do siebie" ${ }^{15}$. Piękno wskazało, odsłoniło Adamowi Chmielowskiemu drogę dobra i prawdę o człowieku, natomiast Józef Chełmoński w prawdzie i pięknie natury zobaczył ukryte w niej dobro i świętość - myślę, że również dla tego, że obu bliski był św. Franciszek z Asyżu.

${ }^{15}$ H. Urs von Balthasar, Chwała, dz. cyt. 


\section{Bibliografia}

M. Gołąb, Chetmoński, Chmielowski, Witkiewicz, Pracownia w Hotelu Europejskim $w$ Warszawie 1874-1883, Muzeum Narodowe w Poznaniu, Poznań 2010.

P. Górska, Paleta i pióro, Kraków 1960.

Józef Chełmoński w świetle korespondencji, oprac. J. Wegner, Wrocław 1953.

Józef Chetmoński (1849-1914), w: W. Juszczak, Malarstwo polskiego modernizmu, Gdańsk 2004, s. 353-373.

M. Masłowski, Malarski żywot Józefa Chełmońskiego, Warszawa 2014.

ks. K. Michalski, Brat Albert, w setna rocznice urodzin (1846-1946), Kraków 1946.

Pisma Adama Chmielowskiego, oprac. ks. A. Schletz, „Nasza Przeszłość” 1963.

prof. Paweł Taranczewski (ur. 1940, Kraków). Studiował malarstwo sztalugowe na krakowskiej Akademii Sztuk Pięknych, które ukończył w roku 1963. Od 1966 jest członkiem Związku Polskich Artystów Plastyków. W latach 1967-1971 studiował filozofię na Wydziale Filozoficzno-Historycznym Uniwersytetu Jagiellońskiego, gdzie doktoryzował się pracą O płaszczyźnie obrazu (1988). W latach 1977 i 1978 przebywał na stypendium w Kolonii (Archiwum Husserla) i w Düsseldorfie (Katedra Filozofii i Estetyki tamtejszej Akademii Sztuki). W latach 1982-1999 pracował w Zakładzie Rysunku Malarstwa i Rzeźby na Wydziale Architektury Politechniki Krakowskiej. W roku 1997 otrzymał tytuł profesora. W latach 1998-2010 piastował stanowisko kierownika Katedry Historii i Teorii Sztuki krakowskiej ASP (mimo przejścia na emeryturę $w$ roku 2008). Równocześnie w latach 2000-2009 wykładał estetykę i zagadnienia sztuki XX w. na Wydziale Filozoficznym Papieskiej Akademii Teologicznej. Przez kilka semestrów prowadził wykład monograficzny o malarstwie Rembrandta w Instytucie Filologii Polskiej Uniwersytetu Jagiellońskiego. Od roku 2009 jest zatrudniony na Wydziale Filozoficznym w Akademii Ignatianum - prowadzi wykłady i seminaria z estetyki i wiedzy o sztuce. Paweł Taranczewski jest autorem wielu tekstów poświęconych polskim malarzom m.in. Janowi Cybisowi, Hannie RudzkiejCybisowej, Janinie Kraupe-Świderskiej, Wacławowi Taranczewskiemu. Swoje teksty, recenzje książek, wystaw oraz tłumaczenia z kilku języków publikował w „Kwartalniku Filozoficznym”, „Estetyce i Krytyce”, „Znaku”, „Twórczości”, „Tygodniku Powszechnym”, „Dekadzie Literackiej” i „Dzienniku Polskim". Brał udział w wielu konferencjach filozoficznych w kraju i za granicą. W czerwcu roku 2006 został wybrany członkiem czynnym Wydziału Twórczości Artystycznej Polskiej Akademii Umiejętności w Krakowie. Miał szereg indywidualnych wystaw malarstwa oraz uczestniczył $w$ wystawach zbiorowych w kraju i za granicą. Ostatnio prezentował prace na wysta- 
wach indywidualnych $w$ Galerii ASP $w$ Krakowie (2016) oraz w Muzeum Historycznym Miasta Tarnobrzega, Zamek Tarnowskich w Dzikowie (2016). Jego obrazy znajdują się w Muzeum Narodowym w Krakowie, w Muzeum ASP w Krakowie oraz kolekcjach prywatnych. 